\title{
The clouded leopard in Sumatra
}

\author{
Charles Santiapillai and Kenneth R. Ashby
}

\begin{abstract}
Few people see the clouded leopard, and its elusiveness makes it a difficult subject for scientific study. In Sumatra, there has been no serious research on the species, and the authors present the scanty information on its distribution there and stress the urgent need for a survey to establish the whereabouts of viable populations.
\end{abstract}

The conversion of primary forest into agricultural holdings has seriously affected the clouded leopard Neofelis nebulosa diardi in Sumatra, where it is estimated that $65-80$ per cent of lowland forest has been lost already (Whitten et al., 1984). The highlands have been less seriously affected, but the scanty information available suggests that perhaps 15 per cent of montane forest has gone.

Before 1900, when most of Sumatra was covered in primary forest, the clouded leopard was probably distributed throughout the island. Now there is direct evidence of the presence of clouded leopard in only about 3 per cent of the island's area (Figure 1). It has been generally believed that the clouded leopard requires primary forest (Harrison, 1974), but available information suggests that it is in fact moderately versatile and adaptable in its requirements, and less strictly arboreal than has been claimed. Its tracks were reported as being frequent in Barisan Selatan National Park, which has suffered seriously from illegal felling, uncontrolled fuel-wood collection and shifting cultivation by transmigrants from Java and Bali (FAO, 1981a). Its tracks have also been seen in a lowland forest in the southern part of Jambi province, where almost half of the forest area had been selectively logged a year previously (Blouch, 1984), and it has been reported from secondary forest in Gunung Leuser National Park (Kurt, 1970). It still occurs in Way Kambas 44
Game Reserve (R. Widodo, pers. comm.), where felling and burning have converted over two-thirds of its lowland dipterocarp forest into Imperata grassland (Caufield, 1984).

However, it is essential that a variety of medium-sized mammals is available as prey, with a substantial proportion being arboreal. Unlike the other felids of Sumatra, it can hunt entirely in the canopy, and it can jump more than $5 \mathrm{~m}$ between trees. Primates, including the larger species, are reported to be the main items of diet, with other prey including deer and pigs (Payne et al., 1985), and even a limited amount of fish in wetland areas.

Figure 1 shows the areas where there is evidence that clouded leopard populations are still probably healthy. These are listed below, and the main source of records of clouded leopards is given in each case.

(a) Gunung Leuser National Park, 10,000 sq $\mathrm{km}$, covering a wide variety of mountain forests (Kurt, 1970).

(b) Torgamba production forest, $1000 \mathrm{sq} \mathrm{km}$, lowland forest (R. Blouch, pers. comm.).

(c) Tigapulu hills, $2000 \mathrm{sq} \mathrm{km}$, mainly below $700 \mathrm{~m}$ and, like Torgamba, has a lowland flora (Blouch and Simbolon, 1985). The forest on the steeper slopes is managed as protection forest, that in the valley as production forest.

(d) Kerinci-Seblat National Park, the largest in Sumatra, 15,800 sq km, following the axis of the Oryx Vol 22 No 1, January 1988 


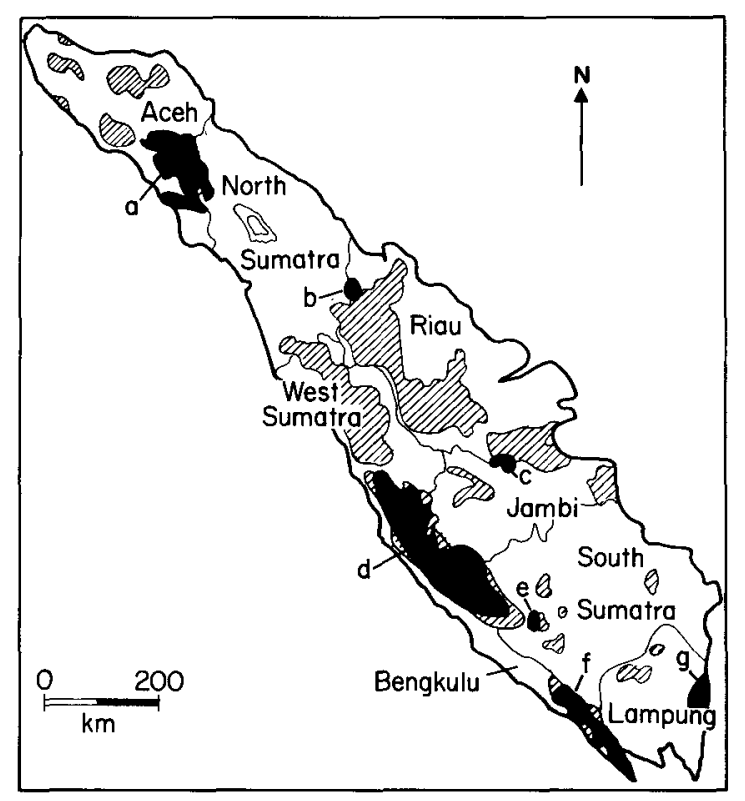

Figure 1. Current distribution of clouded leopard in Sumatra.

Solid shading: areas where there is positive evidence of presence. (a) Gunung Leuser National Park, (b) Torgamba production forest, (c) Tigapulu hills, (d) Kerinci-Seblat National Park, (e) Gumai Pasemah Game Reserve, (f) Barisan Selatan National Park, (g) Way Kambas Game Reserve.

Cross hatching: extent of additional suitable habitat, but where positive evidence of presence is not available. The area was determined in a study to establish the current probable distribution of the Sumatran tiger, a species whose requirements are similar to those of the clouded leopard (Santiapillai and Widodo, 1985).

mountain chain from north-west to south-east, and overlapping the borders of four provinces (FAO, 1981b).

(e) Gumai Pasemah Game Reserve, $450 \mathrm{sq} \mathrm{km}$, partially logged montane forest (Blouch, 1984). Primary tree cover remains good on the lower slopes of the reserve.

(f) Barisan Selatan National Park, $3500 \mathrm{sq} \mathrm{km}$, modified lowland forest (FAO, 1981a).

(g) Way Kambas Game Reserve, $1300 \mathrm{sq} \mathrm{km}$, modified lowland forest on the eastern coast ( $R$. Widodo, pers. comm.).

It is quite possible that the species survives in good habitat elsewhere (Figure 1). Given the large areas where the clouded leopard may be present, but has not yet been searched for, one could maintain that the situation, although clearly requiring monitoring, is not yet serious. It would be more prudent, however, to plan on the basis that there are only two known populations of clouded leopard that appear to be safe from immediate threat, those in Gunung Leuser and Kerinci-Seblat National Parks. Elsewhere the clouded leopard is threatened not only by habitat loss, but also by poisoning and the high commercial value of the pelt in the illegal trade.

There is an urgent need for a survey to determine the whereabouts of viable populations, particularly in the remaining unfragmented lowland forest. Even more important, the problem concerning the clouded leopard provides yet one more compelling argument for ending the indiscriminate felling and deforestation that have been sweeping across Sumatra.

\section{References}

Blouch, R.A. 1984. Current Status of the Sumatran Rhino and other Large Mammals in Southem Sumatra. IUCN/ WWF 3033 Report No: 4 Bogor.

Blouch, R.A. and Simbolon, K. 1985. Elephants in Northem Sumatra. IUCN/WWF 3033 Report No: 9 , Bogor.

Caufield, C. 1984. In the Rainforest. Heinemann, London.

FAO, 1981a. Barisan Selatan Game Reserve Management Plan 1982-1987. FAO Field Report No: 21, Bogor.

FAO, 1981b. Kerinci-Seblat Proposed National Park Preliminary Management Plan 1982-1987. FAO Field Report No: 14, Bogor.

Harrison, J. 1974. An Introduction to Mammals of Singapore and Malaya. Malayan Nature Soc., Singapore.

Kurt, F. 1970. Leuser Reserve (Sumatra). Final Report to IUCN/SSC and WWF International of WWF Project 596, Bogor.

Payne, J., Francis, C.M. and Phillips, K. 1985. A Field Guide to the Mammals of Bomeo. The Sabah Society, Kota Kinabulu.

Santiapillai, C. and Widodo, S.R. 1985. On the status of the Tiger (Panthera tigris sumatrae Pocock, 1829) in Sumatra. Tigerpaper (FAO, Asia and the Pacific Region), 12, 23-29.

Whitten, A.J., Damanik, S.J., Anwar, J. and Hisyam, N. 1984. The Ecology of Sumatra. Gadjah Mada University Press, Yogyakarta.

Charles Santiapillai, WWF/IUCN Indonesia Programme, PO Box 133, Bogor, Indonesia.

Kenneth R. Ashby, Zoology Department, University of Durham, Durham DH1 3LE, UK. 